\title{
Age Differences of Human Frontal Sinus Measurements using CT Scan
}

\author{
Mohammad Ahmad Abdalla ${ }^{*}$ (iD
}

1. Dept. of Human Anatomy, College of Medicine, Tikrit University, Tikrit, Iraq

\begin{tabular}{|c|c|}
\hline Article Info & ABSTRACT \\
\hline doi $10.30699 /$ jambs.29.136.293 & \multirow{3}{*}{$\begin{array}{l}\text { Background \& Objective: The frontal sinus is regarded as one of the humar } \\
\text { paranasal sinuses located in the frontal bone as a triangular-shaped cavity, which } \\
\text { originates as separated space from the anterior ethmoid cells. Computec } \\
\text { Tomography (CT) is a completely non-destructive technique that uses a high } \\
\text { density of contrast to identify the air inside any bony sinus with soft tissue } \\
\text { demarcated by air within a particular nasal cavity. This study aimed to measure the } \\
\text { anteroposterior length, width, and height of frontal sinus in different age groups or } \\
\text { both genders with axial, coronal, and sagittal CT scans, as well as identifying the } \\
\text { pneumatization of that sinus according to the extent represented by CT scans. }\end{array}$} \\
\hline $\begin{array}{l}\text { Received: 2020/09/11; } \\
\text { Accepted: 2021/03/17; } \\
\text { Published Online: } 04 \text { Apr 2021; }\end{array}$ & \\
\hline $\begin{array}{l}\text { Use your device to scan and read the } \\
\text { article online }\end{array}$ & \\
\hline 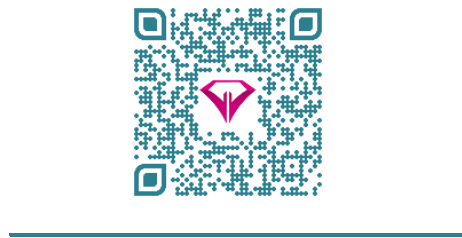 & $\begin{array}{l}\text { Materials \& Methods: A prospective study was conducted on a random sample of } \\
250 \text { subjects attending the Radiology Section of both Baghdad Medical City and Salah } \\
\text { Al-Deen Teaching Hospitals from February } 2019 \text { to January } 2020 \text {. Different age and } \\
\text { gender groups from these individuals underwent measurement of the anteroposterior } \\
\text { length, width, and height of frontal paranasal sinus in axial, sagittal, and coronal CT } \\
\text { scans. }\end{array}$ \\
\hline \multirow[t]{3}{*}{$\begin{array}{l}\text { Corresponding Information: } \\
\text { Mohammad Ahmad Abdalla } \\
\text { Dept. of Human Anatomy, College of } \\
\text { Medicine, Tikrit University, Tikrit, Iraq } \\
\text { E-Mail: } \\
\text { dr.mohammad68@tu.edu.iq }\end{array}$} & $\begin{array}{l}\text { Results: The frontal air cells belonged to the anterior group including four types and } \\
\text { one medial group with a prevalence of } 37.6 \%, 18 \%, 16.8 \%, 6.8 \% \text {, and } 20.8 \% \text {, } \\
\text { respectively, through a series of CT scan sections. The mean values of frontal sinus } \\
\text { length, width, and height for males were } 19.8 \pm 8.7 \mathrm{~mm}, 32.8 \pm 8.7 \mathrm{~mm} \text {, and } 29.7 \pm 8.8 \\
\text { mm, respectively; and for females were } 14.9 \pm 8.3 \mathrm{~mm}, 25.4 \pm 9.2 \mathrm{~mm} \text {, and } 22.5 \pm 9.2 \\
\mathrm{~mm} \text {, respectively. }\end{array}$ \\
\hline & $\begin{array}{l}\text { Conclusion: A high incidence of frontal sinus cell types and supraorbital cells } \\
\text { suggested the superioposterior partition of frontal sinus which tends to demonstrate } \\
\text { more pneumatization than other partitions. }\end{array}$ \\
\hline & Keywords: Computed tomography (CT), Frontal sinus, Paranasal sinuses \\
\hline (1) ${ }_{\mathrm{BY}} \mathrm{NC}$ & \\
\hline
\end{tabular}

\section{Introduction}

In Latin "sinus" means "fold" or "pocket", and the frontal sinus is called sinus frontalis, which is situated within the frontal bone, posterior to the superciliary arch. It is characterized as paired, lobulated, and irregular chambers that open into the corresponding infundibulum of the middle meatus (1).

The frontal sinus is one of the human paranasal sinuses that originates from anterior ethmoid cells; at the end of the first year of life, its migration to the frontal bone occurs. At about eight years of age, it is pneumatized rapidly to become an obvious radiographical space that projects over the orbital rim, while the final size occurs at the approximate age of 20 (2). The structure of the frontal sinus remains stable during the entire life until older ages as it is pneumatized gradually due to atrophic alterations; since it is the last sinus that develops with a high variable size ranging from several cubic centimeters to a characteristic size, which may fill the whole frontal bone region (3).
The sinus floor composes the roof of the orbit, while its anterior boundary consists of skull bone that tends to be of a considerable thickness compared to its posterior boundary which is in a close relation with the anterior cranial fossa. A midline septum locates inside the sinus as an imperfect septation starts from its roof and leads to the sinus scalloped appearance $(4,5)$.

The frontal sinus is absent in approximately $4 \%$ of individuals, while another $4-5 \%$ have only small superior frontal air cells. A complete septum divides the frontal sinus into two sides that may be subdivided into further recesses or compartments by an incomplete or even complete bony septum (6).

The right and left frontal sinuses show independent development with various rates of resorbed bone tissues; therefore, significant asymmetry may be found between the two sides in a particular person. Difference in the size and dimension of frontal sinuses may be usually recognized in the same-aged population (7). 
Computed Tomography (CT) is a completely nondestructive medical technique that is used to visualize the interior features of opaque solid materials and obtain digital data about their $3 \mathrm{D}$ configurations. $\mathrm{CT}$ and to a lesser degree, MRI, support radiologists and otolaryngologists with good information about ostiomeatal complex, and also other paranasal or nasal sinus anatomical features (8); therefore, cross-sectional CT images of the maxillofacial region reveal soft tissues present at the paranasal air sinuses, nasal cavities, orbits, and different intracranial structures $(9,10)$.

This study aimed to measure the anteroposterior length, width, and height of the frontal sinus in different age and gender groups with axial, coronal, and sagittal CT scans. It also intended to identify the pneumatization of that sinus according to the extent represented by CT scans. Furthermore, depending on data obtained from these CT scan images, this study aimed to identify demographic information including age, gender, race, and ethnicity of each alive or even dead individual.

\section{Materials and Methods}

A random sample of 250 cases, apparently healthy normal individuals, attending the Radiology Section of both Baghdad Medical City and Salah Al-Deen Teaching Hospitals in Iraq were included in this study. This prospective study was carried out during February 2019January 2020, and the included individuals of both genders were ordered in different age groups (Table 1).

The Medical Ethics Committee of Tikrit University, College of Medicine, approved this study (Code IQ.TUCOM.REC.20.82137). Ethical approval statements were also acquired for all participants, based on World Medical Association Declaration of Helsinki, with the last (Edinburgh 2000) revision.

The current study included individuals who had frequent complaints of headaches. While patients with a history of surgical interference, trauma, or any pathological lesion at the maxillofacial area were excluded from the present study. The included patients were admitted to the Radiology Section to have CT scans for brain and paranasal sinuses. It is worth to note that no pathological findings were detected in the sinuses.

\section{Spiral CT Scan Examination}

Sections of $5 \mathrm{~mm}$ were often quite enough to evaluate various sinonasal or basal skull structures, but thinner sections of $3 \mathrm{~mm}$ were used for identifying small structures and evaluating the entire ostiomeatal unit. In terms of filming, intermediate window width/level (W/L) technique was recommended $(2500 / 250, \mathrm{~W} / \mathrm{L})(11,12)$.

The imaging protocols used in the current study included: 3 to $5 \mathrm{~mm}$ slice thickness, $140 \mathrm{kVp}, 94 \mathrm{mAs}$, 2000 window width, 400 window level, and 35-45-second scan time.

Some criteria depended on the production of accurate measurements for each sinus $(13$ - 15) using a 3D program of CT Siemens, workstations with a maximum resolution of $1280 \times 1042$ full-screen formats, and a picture size of $360 \mathrm{~mm} \times 288 \mathrm{~mm}$. The workstation permitted synchronous viewing of the particular reference point at three view sections (the axial, sagittal, and coronal); then these images were captured in JPEG format and downloaded on CD to transfer its data. Specimens were digitally photographed using a Panasonic HDD-H80 camera.

\section{Statistical Analysis}

The data were transferred to a database computer and then entered into the SPSS software version 13.0 (SPSS Inc., Chicago, IL., USA). The frequency distribution of selected sample variables was carried out first. Then the quantitative outcome variables (measurements) were put in a normal distribution curve and tabulated with mean, standard deviation, and statistical parametric tests for significance. The independent samples T-test and ANOVA test were used to evaluate any statistical significance, and a P-value less than 0.05 was regarded as statistically significant.

Table 1. Distribution of participating individuals according to age and gender.

\begin{tabular}{|c|c|c|c|c|}
\hline Groups & Age & Male No. & Female No. & Total No. \\
\hline Group 1 & $20-29$ years & 35 & 30 & 65 \\
\hline Group 2 & $30-39$ years & 32 & 31 & 63 \\
\hline Group 3 & $40-49$ years & 30 & 28 & 58 \\
\hline Group 4 & $50-59$ years & 33 & 31 & 64 \\
\hline \multicolumn{2}{|c|}{ Total } & 130 & 120 & 250 \\
\hline
\end{tabular}




\section{Results}

The boundaries of the frontal sinuses are often scalloped, producing septa that project to the sinus space. The principal intersinus septum is located inferiorly in the midline, though it can drift an angle away to right or left of the midline where it elevates superiorly. The roof of the orbit may be associated with two diverse pathways of pneumatization; in the first, there was an inferior recess for the frontal sinus that extends backward or posteriorly and this finding was shown in $64 \%$ of cases; in the second, the supraorbital cells may extend independently to the orbital roof as was seen in $36 \%$ of cases (Figure 1-A). The uniqueness between those sinuses was best achieved in coronal section images, as supraorbital cells were viewed as lateral arching extensions for anterior ethmoidal cells that extend to the orbital plate dipole (Figure 1-B), but axial and sagittal CT scans gave a clear picture of the posterior border of those recesses.

The frontal cells belonged to the anterior group (Types 1 to 4 ) and medial group (the interfrontal sinus septal cell); however, these cells might be seen more obviously by the sagittal CT section than both the coronal and axial sections and could be described as the following:

1- First Type Frontal Cell: It was demonstrated as a solitary cell over the recognized agger nasi cell, with its posterior boundary, not the base of the skull but the free part within the frontal recess. This type was prevalent in $37.6 \%$ of cases. It was obvious in the sagittal and coronal CT sections (Figure 2-A).

2- Second Type Frontal Cell: It resembled a tier of two or even more anteriorly located cells, which pneumatized over agger nasi cells, with its posterior boundary, not the base of the skull but the free part

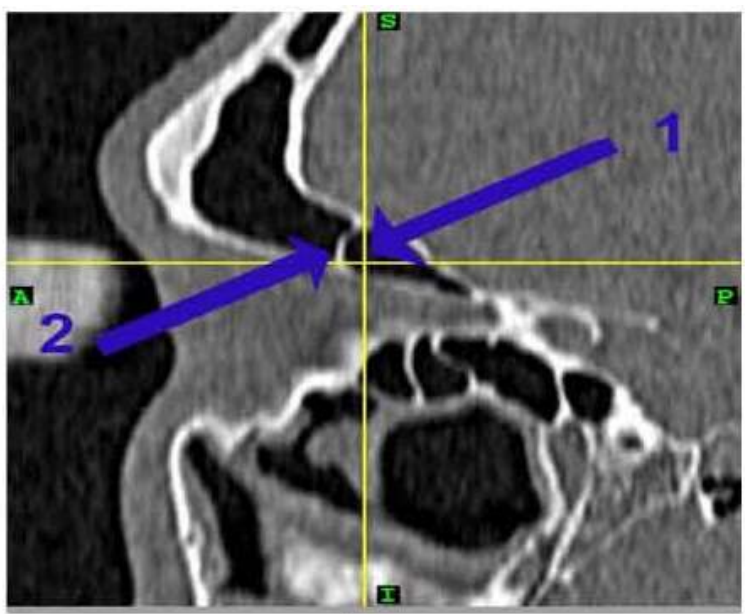

A within the frontal recess. This type was found in $18 \%$ of cases that were clear in the sagittal and coronal CT sections (Figure 2-B).

3- Third Type Frontal Cell: It appeared as a solitary large cell over agger nasi that pneumatized along the internal side of the anterior frontal paranasal sinus table from well-visible anterior recess. This type of cell extended away to the frontal sinus with its superior boundary including above the internal side of the anterior frontal paranasal sinus table (obvious in sagittal CT view). Its posterior boundary represents not the base of the skull but the free part within the frontal recess. This type was prevalent in $16.8 \%$ of cases that are well shown in sagittal and coronal CT sections (Figure 2-C).

4- Fourth Type Frontal Cell: It presented as a separated cell inside the frontal sinus and over agger nasi, which appeared like a "balloon on a string" in sagittal CT view (Figure 2-D) and appeared like an "air bubble" in coronal CT image (Figure 2-E). The inferior and anterior boundary was the floor of the frontal sinus or anterior table of it, while its posterior margin was a cell boundary but not the posterior table of the frontal sinus. Only $6.8 \%$ of cases had this type of cell and its identification required both sagittal and coronal CT sections.

5- Interfrontal Sinus Septal Cell: It seemed to be pneumatized from the septum of the frontal sinus, which drains to a single particular frontal recess that is also associated with pneumatization of crista galli. This type of cell was prevalent in $20.8 \%$ of cases. It is clear in the coronal and axial CT sections (Figure 2-F).

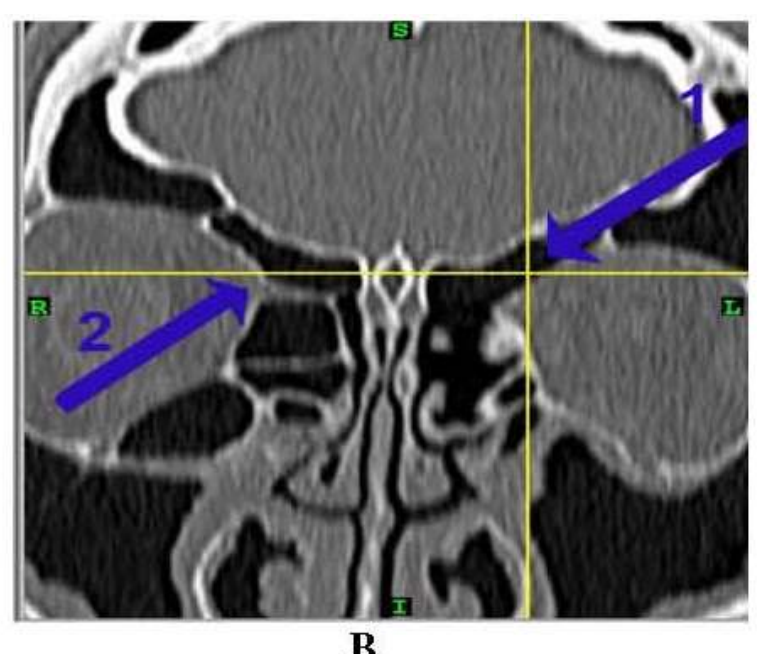

B

Figure 1. Supraorbital Cell and Septal Frontal sinus in A-Sagittal Section and B-Coronal Section.

*(1) Supraorbital Cell. *(2) Septal Frontal Sinus. 


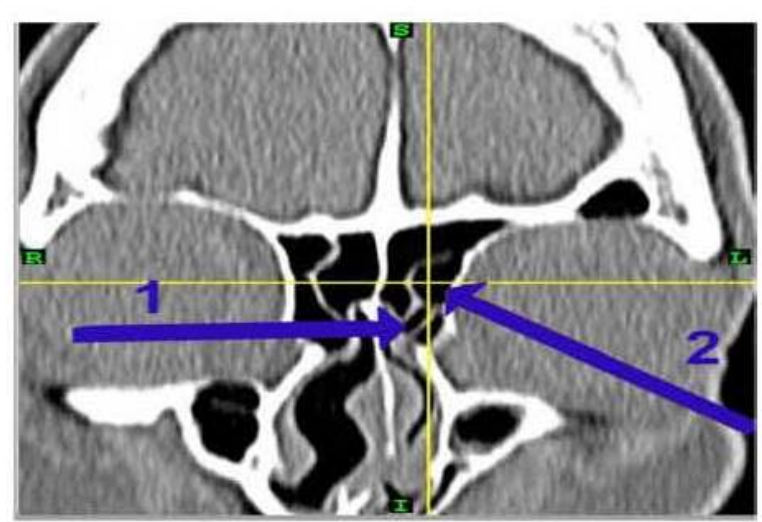

A

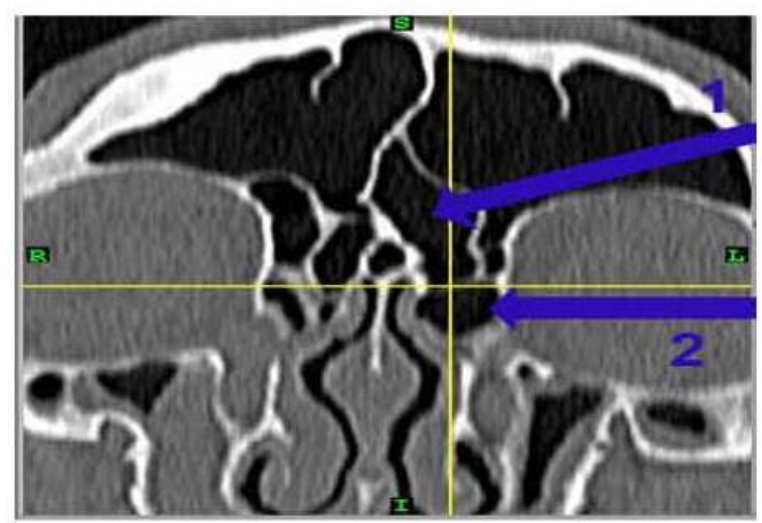

C

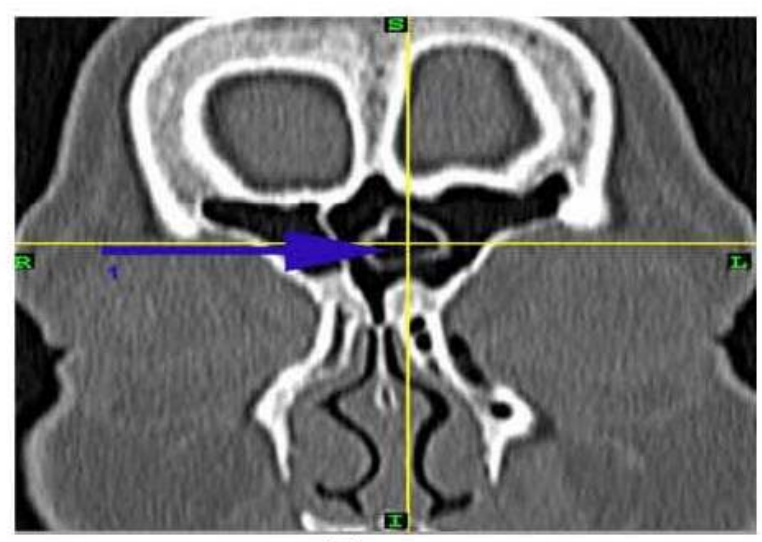

E

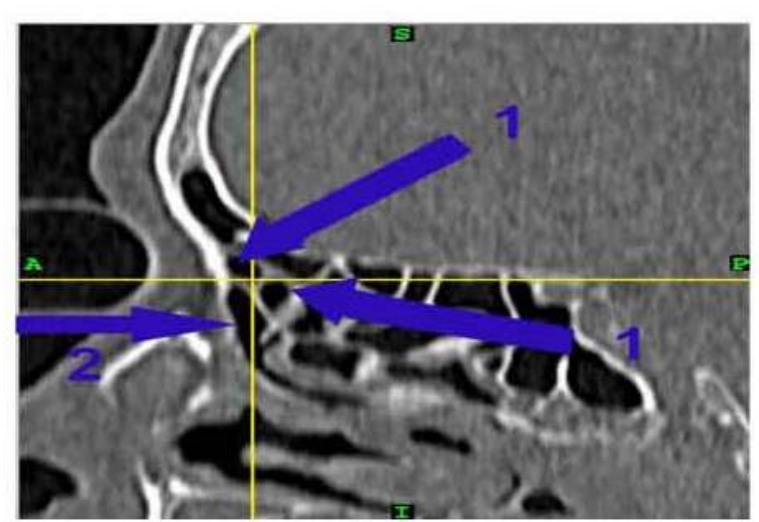

B

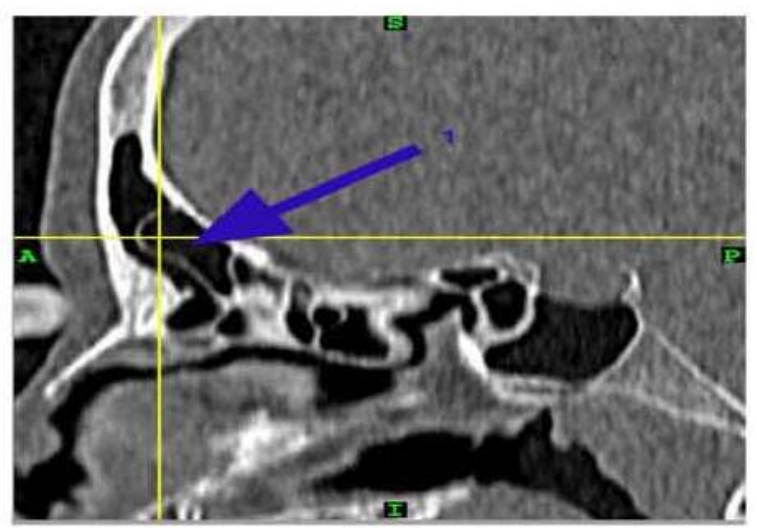

D

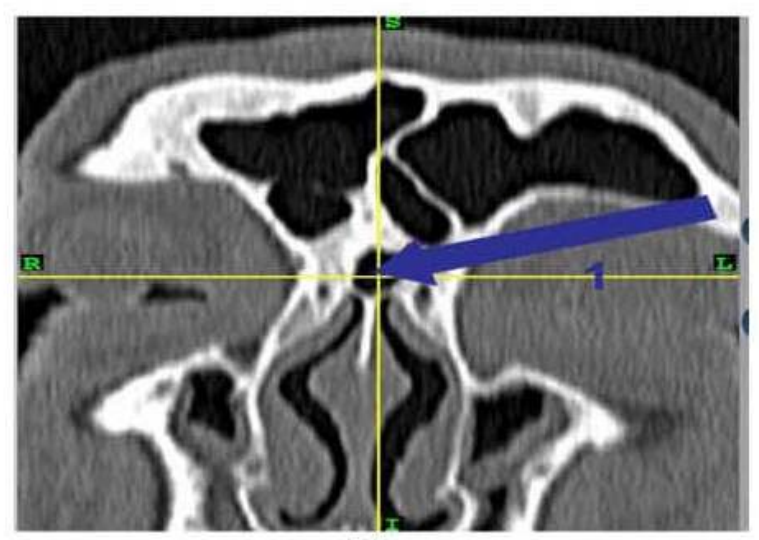

F

Figure 2. Different Types of Frontal Cells in Various CT scan sections. A: Coronal Section Showing: (1)*The Agger Nasi Cell. (2)*Single Cell of First Type Frontal Cell. B: Sagittal Section Showing: (1)*Two Cells of Second Type Frontal Cell. (2)*The Agger Nasi Cell. C: Coronal Section Showing: (1)*Single Large Cell of Third Type Frontal Cell. (2)* The Agger Nasi Cell. D: Sagittal Section Showing: (1)*Fourth Type Frontal Cell which Apparently Isolated Cell within Frontal Sinus Appears as a "Balloon on a String" and above Agger Nasi Cell. E: Coronal Section Showing: (1)* Fourth Type Frontal Cell which Apparently Isolated Cell within Frontal Sinus Appears as an "Air Bubble" and above Agger Nasi Cell. F: Coronal Section Showing: (1)* The Interfrontal Sinus Septal Cell.

\section{Frontal Sinus Length}

In males, the mean lengths for the right and the left frontal sinuses were $20.1 \pm 8.8 \mathrm{~mm}$ and $19.4 \pm 8.4 \mathrm{~mm}$, respectively. On the contrary, in females, the mean lengths for the right and the left frontal sinuses were
$15.3 \pm 7.4 \mathrm{~mm}$ and $14.5 \pm 8.7 \mathrm{~mm}$, respectively. No statistically significant side difference was noticed for both sexes $(P>0.05)$; but concerning sex differences, a higher significant difference was revealed in males for 
frontal sinus lengths of both sides in comparison with females, as shown in Table 2.

The first group on the right side represented the maximum length of frontal sinus in males $(22.4 \pm 9.2 \mathrm{~mm})$, while the second group on the right side represented the minimum length of frontal sinus in males $(17.0 \pm 7.4 \mathrm{~mm})$. On the other hand, the third group on the right side represented the maximum length of frontal sinus in females $(16.2 \pm 7.2 \mathrm{~mm})$ and the second group on the left side represented the minimum length of frontal sinus in females $(13.4 \pm 7.4 \mathrm{~mm})$. Both sides for both sexes and various age groups appeared to show significant differences except for the left frontal sinus in females that did not record any significant difference when ANOVA test was used (Table 3).

\section{Frontal Sinus Width}

In males, the mean widths for the right and the left frontal sinuses were $30.5 \pm 9.1 \mathrm{~mm}$ and $35.1 \pm 7.2 \mathrm{~mm}$, respectively. While in females, $24.2 \pm 8.4 \mathrm{~mm}$ and $26.6 \pm 9.9 \mathrm{~mm}$ were the mean widths for the right and the left frontal sinuses, respectively. Males showed higher statistically significant side difference in comparison with females; while, regarding gender difference, side width for both frontal sinuses was significantly different between males and females, which is seen in Table 2.

In this study, the maximum width of frontal sinus in males $(38.0 \pm 7.2 \mathrm{~mm})$ was represented by the fourth group on the left side, but the third group on the right side represented the minimum width $(28.0 \pm 9.4 \mathrm{~mm})$. While for females, the fourth group on the left side represented the maximum width of frontal sinus $(28.1 \pm 9.5 \mathrm{~mm})$ and the first group on the right side represented the minimum width of frontal sinus (21.3 \pm $8.7 \mathrm{~mm})$. A significant difference was found among all age groups of both sides and of both sexes $(P<0.05)$ when ANOVA test results were used, as shown in Table 3.

\section{Frontal Sinus Height}

In males, the mean height of right frontal sinus was $29.1 \pm 8.5 \mathrm{~mm}$, whereas that of the left side was $30.4 \pm 9.1$ $\mathrm{mm}$. The mean height for the right frontal sinus in females was $20.9 \pm 8.6 \mathrm{~mm}$ and for the left side was $24.1 \pm 9.8 \mathrm{~mm}$. Only females recorded a high significant difference for both sides; otherwise, male individuals revealed a higher significant difference for the mean height of frontal paranasal sinus in both sides in comparison with females, as presented in Table 2.

Considering the age, the third group on the left side had the maximum height of frontal sinus for males $(33.1 \pm 8.4$ $\mathrm{mm}$ ) and the first group on the right side had the minimum height $(28.2 \pm 9.0 \mathrm{~mm})$. The second group on the left side had the maximum height of frontal paranasal sinus for females $(26.1 \pm 9.6 \mathrm{~mm})$, and the second group but on the right side had the minimum height $(19.6 \pm 8.4 \mathrm{~mm})$. A highly significant difference was observed for both sides of frontal sinuses for both sexes, except for the height of right frontal sinus in males which revealed no significant difference among all groups $(P>0.05)$ when ANOVA test findings were used, as shown in Table 3.

Table 2. Frontal sinus length, width, and height measurements for both gender done by ct scan.

\begin{tabular}{|c|c|c|c|c|c|c|c|c|c|}
\hline & \multicolumn{3}{|c|}{ Male } & \multicolumn{3}{|c|}{ Female } & \multicolumn{3}{|c|}{ Both Gender } \\
\hline & Range & Mean & SD & Range & Mean & SD & Range & Mean & SD \\
\hline $\begin{array}{l}\text { Right Frontal sinus length } \\
\left(\begin{array}{c}(\mathrm{mm})\end{array}\right.\end{array}$ & $(7.1-46.0)$ & 20.1 & 8.8 & $(5.2-41.3)$ & 15.3 & 7.4 & $(5.2-46.0)$ & 17.7 & 8.1 \\
\hline $\begin{array}{l}\text { Left Frontal sinus length } \\
(\mathrm{mm})\end{array}$ & $(5.4-41.1)$ & 19.4 & 8.4 & $(6.6-44.5)$ & 14.5 & 8.7 & $(5.4-44.5)$ & 17.0 & 8.6 \\
\hline $\begin{array}{c}\text { Right - left Frontal sinus } \\
\text { length (mm) }\end{array}$ & $(5.4-46.0)$ & 19.8 & 8.7 & $(5.2-44.5)$ & 14.9 & 8.3 & $(5.2-46.0)$ & 17.3 & 8.3 \\
\hline $\begin{array}{l}\text { Right - Left Frontal sinus } \\
\text { length difference (mm) }\end{array}$ & $(-1.7$ to 5.4$)$ & 0.7 & 1.3 & $(-1.1$ to 7.3$)$ & 0.8 & 2.1 & $(-1.7$ to 7.3$)$ & 0.7 & 1.7 \\
\hline $\begin{array}{l}\text { Right Frontal sinus width } \\
\left(\begin{array}{l}(\mathrm{mm})\end{array}\right.\end{array}$ & $(13.7-49.2)$ & 30.5 & 9.1 & $(12.7-43.0)$ & 24.2 & 8.4 & $(12.7-49.2)$ & 27.3 & 8.8 \\
\hline $\begin{array}{l}\text { Left Frontal sinus width } \\
\qquad(\mathrm{mm})\end{array}$ & $(15.4-47.7)$ & 35.1 & 7.2 & $(8.1-55.1)$ & 26.6 & 9.9 & $(8.1-55.1)$ & 30.8 & 8.6 \\
\hline $\begin{array}{l}\text { Right - left Frontal sinus } \\
\text { width (mm) }\end{array}$ & $(13.7-49.2)$ & 32.8 & 8.7 & $(8.1-55.1)$ & 25.4 & 9.2 & $(8.1-55.1)$ & 29.1 & 9.0 \\
\hline $\begin{array}{l}\text { Right - Left Frontal sinus } \\
\text { width difference (mm) }\end{array}$ & $(-4.2$ to 6.1$)$ & -4.6 & 2.2 & $(-2.6$ to 8.5$)$ & -2.4 & 5.1 & $(-4.2$ to 8.5$)$ & -3.5 & 3.7 \\
\hline $\begin{array}{l}\text { Right Frontal sinus height } \\
\text { (mm) }\end{array}$ & $(11.2-49.1)$ & 29.1 & 8.5 & $(8.4-42.5)$ & 20.9 & 8.6 & $(8.4-49.1)$ & 25.0 & 8.6 \\
\hline $\begin{array}{l}\text { Left Frontal sinus height } \\
\text { (mm) }\end{array}$ & $(13.4-53.1)$ & 30.4 & 9.1 & $(7.2-56.1)$ & 24.1 & 9.8 & $(7.2-56.1)$ & 27.3 & 9.5 \\
\hline $\begin{array}{l}\text { Right - left Frontal sinus } \\
\text { height (mm) }\end{array}$ & $(11.2-53.1)$ & 29.7 & 8.8 & $(7.2-56.1)$ & 22.5 & 9.2 & $(7.2-56.1)$ & 26.7 & 9.1 \\
\hline $\begin{array}{l}\text { Right - Left Frontal sinus } \\
\text { height difference }(\mathrm{mm})\end{array}$ & $(-3.2$ to 4.5$)$ & -1.3 & 2.1 & $(-1.4$ to 8.4$)$ & -3.2 & 1.6 & $(-3.2$ to 8.4$)$ & -2.3 & 1.8 \\
\hline
\end{tabular}


Table 3. Age difference of frontal sinus length, width, and height measurements for both gender done by ct scan.

\begin{tabular}{|c|c|c|c|c|c|c|c|c|c|c|c|c|c|}
\hline & & \multicolumn{3}{|c|}{ Group 1} & \multicolumn{3}{|c|}{ Group 2} & \multicolumn{3}{|c|}{ Group 3} & \multicolumn{3}{|c|}{ Group 4} \\
\hline & & Range & Mean & SD & Range & Mean & SD & Range & Mean & SD & Range & Mean & SD \\
\hline \multirow{4}{*}{$\frac{\stackrel{0}{\pi}}{\Sigma}$} & $\begin{array}{l}\text { Right Frontal } \\
\text { sinus length } \\
(\mathrm{mm})\end{array}$ & $(9.2-45.2)$ & 22.4 & 9.2 & $(7.1-44.3)$ & 17.0 & 7.4 & $(9.4-46.0)$ & 18.9 & 9.5 & $(8.3-44.6)$ & 22.1 & 9.1 \\
\hline & $\begin{array}{c}\text { Left Frontal } \\
\text { sinus length } \\
\text { (mm) }\end{array}$ & $(7.5-39.8)$ & 21.2 & 8.3 & $(6.2-41.1)$ & 17.4 & 9.1 & $(5.4-39.5)$ & 20.2 & 7.8 & $(8.1-40.4)$ & 18.8 & 8.4 \\
\hline & $\begin{array}{l}\text { Right Frontal } \\
\text { sinus width } \\
\text { (mm) }\end{array}$ & $(13.7-46.5)$ & 28.4 & 8.8 & $(14.8-47.1)$ & 33.1 & 8.5 & $(15.1-47.7)$ & 28.0 & 9.4 & $(15.7-49.2)$ & 32.5 & 9.7 \\
\hline & $\begin{array}{c}\text { Left Frontal } \\
\text { sinus width } \\
\text { (mm) }\end{array}$ & $(17.2-46.0)$ & 36.1 & 7.0 & $(16.4-46.3)$ & 34.2 & 6.4 & $(15.4-45.3)$ & 32.1 & 8.2 & $(16.1-47.7)$ & 38.0 & 7.2 \\
\hline \multirow{8}{*}{ 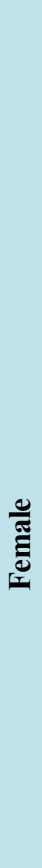 } & $\begin{array}{c}\text { Right Frontal } \\
\text { sinus height } \\
\text { (mm) }\end{array}$ & $(11.2-47.5)$ & 28.2 & 9.0 & $(13.1-49.1)$ & 28.6 & 8.8 & $(14.4-46.4)$ & 30.1 & 7.5 & $(14.6-48.5)$ & 29.5 & 8.7 \\
\hline & $\begin{array}{l}\text { Left Frontal } \\
\text { sinus height } \\
(\mathrm{mm})\end{array}$ & $(15.1-50.2)$ & 31.2 & 8.7 & $(14.5-53.1)$ & 28.7 & 10.1 & $(16.7-49.1)$ & 33.1 & 8.4 & $(13.4-51.2)$ & 28.6 & 9.2 \\
\hline & $\begin{array}{c}\text { Right Frontal } \\
\text { sinus length } \\
(\mathrm{mm})\end{array}$ & $(5.2-40.6)$ & 13.5 & 8.3 & $(9.4-38.7)$ & 16.1 & 6.3 & $(6.4-39.5)$ & 16.2 & 7.2 & $(7.5-41.3)$ & 15.4 & 7.8 \\
\hline & $\begin{array}{c}\text { Left Frontal } \\
\text { sinus length } \\
\text { (mm) }\end{array}$ & $(9.1-42.1)$ & 14.0 & 9.3 & $(7.2-41.2)$ & 13.4 & 7.4 & $(6.6-40.1)$ & 15.6 & 9.2 & $(8.4-44.5)$ & 15.0 & 8.9 \\
\hline & $\begin{array}{c}\text { Right Frontal } \\
\text { sinus width } \\
\text { (mm) }\end{array}$ & $(14.1-43.0)$ & 21.3 & 8.7 & $(13.6-40.1)$ & 25.1 & 8.5 & $(15.5-42.2)$ & 24.3 & 8.7 & $(12.7-39.8)$ & 26.1 & 7.7 \\
\hline & $\begin{array}{c}\text { Left Frontal } \\
\text { sinus width } \\
\text { (mm) }\end{array}$ & $(10.2-53.6)$ & 25.4 & 10.7 & $(13.2-50.4)$ & 26.8 & 9.6 & $(8.1-52.3)$ & 26.1 & 9.8 & $(11.4-55.1)$ & 28.1 & 9.5 \\
\hline & $\begin{array}{c}\text { Right Frontal } \\
\text { sinus height } \\
\text { (mm) }\end{array}$ & $(8.4-38.6)$ & 19.8 & 9.2 & $(11.7-39.1)$ & 19.6 & 8.4 & $(13.5-42.5)$ & 21.3 & 8.7 & $(10.1-40.1)$ & 22.9 & 8.1 \\
\hline & $\begin{array}{l}\text { Left Frontal } \\
\text { sinus height } \\
(\mathrm{mm})\end{array}$ & $(10.1-50.6)$ & 23.6 & 10.1 & $(7.2-52.1)$ & 26.1 & 9.6 & $(11.2-56.1)$ & 24.4 & 10.6 & $(13.5-55.2)$ & 22.3 & 8.9 \\
\hline
\end{tabular}

\section{Discussion}

Identification of the agger nasi cells was particularly important for the demonstration of the four frontal sinus cell types because of the close relation of those cells with agger nasi cells. As the agger nasi roof forms the anterior frontal sinus floor, the anteriorly located cells of the frontal sinus are absent. The incidence of these frontal sinus cell types appeared in CT scanned cases were $37.6 \%, 18 \%, 16.8 \%, 6.8 \%$, and $20.8 \%$, respectively. These findings were fairly similar to the results of Eweiss and Khalil (16) who demonstrated them as $50 \%, 26.5 \%, 6 \%, 3.5 \%$, and $14.0 \%$, respectively.

In the current study, the recorded mean value of frontal sinus (anteroposterior length) for males was $19.8 \pm 8.7 \mathrm{~mm}$, and for females was $14.9 \pm 8.3 \mathrm{~mm}$, meaning that the anteroposterior length of frontal sinuses was greater in males compared to females. These findings disagreed with those of Tatlisumak et al. (17) who made measurements on frontal sinuses of 100 cases from Turkish people and recorded that the right and the left anteroposterior lengths for males were $12.35 \pm 5.14 \mathrm{~mm}$ and $13.84 \pm 7.32 \mathrm{~mm}$, and for females were $10.93 \pm 5.05 \mathrm{~mm}$ and $12.11 \pm 5.20 \mathrm{~mm}$, respectively. However, the anteroposterior length reported in this study was greater than the length recorded by the above-mentioned study; these differences in readings might be attributed to racial differences.

Based on the findings of this study, the mean width of the frontal sinus was $32.8 \pm 8.7 \mathrm{~mm}$ in males and $25.4 \pm 9.2 \mathrm{~mm}$ in females. These results showed that the frontal sinus was wider in males compared to females. In a previous study done by Riepert et al. (18), data were collected from 30 macerated skulls ( 8 females and 22 males); the study displayed the mean width for both frontal sinus sides as $27.04 \mathrm{~mm}$ and $28.37 \mathrm{~mm}$, respectively. Compared to the findings of the present study, the mean width of both frontal sinus sides was lower than the male mean values and higher than the female mean values; this might be a result of the small 
sample size used in their study or due to the anatomic variations in the studied samples. This study agrees with the current study in that the width of right frontal paranasal sinus is narrower compared to the left side.

The mean height of the frontal sinus in the current study was $29.7 \pm 8.8 \mathrm{~mm}$ in males and $22.5 \pm 9.2 \mathrm{~mm}$ in females. From these results, one can observe that the height of the frontal sinus in males was greater than that in females. Akhlaghi et al. (19) reported that the average height for frontal sinus was $24.3 \mathrm{~mm}$ which is lower than the average height of the present study (29.3 $\mathrm{mm}$ ) when both sides and both genders are considered together.

Another anatomical study was done by Ruiz and Wafae (20), who made the measurements of the skull and frontal sinus for 50 skulls of adult individuals from both genders and two distinct ethnic groups lived in Brazil and randomly selected from the bone museum. They found that the maximum height of the sinus ranged from $20-80 \mathrm{~mm}$ with a mean height of 45.95 $\mathrm{mm}$. Compared with the previous study, the maximum height of the sinus was higher than the recorded findings of the present study, which were attributed to a difference in methodology, as well as ethnic variation.

The mean height for both frontal sinus sides was $13.67 \mathrm{~mm}$ in the current study, and $13.66 \mathrm{~mm}$ in the study of Soares et al. (21) that was much lower than that of the present study for both genders. This could be ascribed to different measurement techniques since they measured the height of the frontal sinus as a distance directly connecting the two highest points or spots of the right/left frontal sinus, which should be vertical on a line connecting the highest points or spots of each orbit. Ribeiro (22) revealed the maximum width of the frontal sinus found in the age group of 6978.5 years and this finding was very closely related to the present study in that it revealed the fourth group on the left side in CT scans of both sexes that had the highest value among the other study age groups.

On the other side, Choby et al. (23) found that the cases in the 29-38.9-year age group had the minimum width of frontal sinus, which agreed with the male finding of the present study but disagreed with the female finding found in the first group. Concerning the height, the mentioned study recorded the maximum height in the third group and the minimum height in the first group. Therefore, in comparison of these results with the results of the current study, it completely agreed to male finding and disagreed with the female finding that was represented by the left side of the second group as the maximum height and the right side of the second group as the minimum height.

Concerning age groups, Wormald et al. (24) reported that the maximum length was in the second group on the left side, which disagreed with this study that revealed the maximum length in the first group on the right side of males and the third group on the right side of females. The maximum width of frontal sinus in the previously mentioned study was reported in the third group on the left side in males; therefore, this finding disagreed with the present study which demonstrated the maximum width for the fourth group on the left side in both genders. The second group on the left side of males had the maximum height in the same previous study, which was in agreement with the finding for the females of this study but disagreed with the male finding that was represented by the third group on the left side. All the minimum findings for the three parameters were in the age group $\geq 61$ years in the previous study. These completely disagreed with the findings of the present study that revealed the second group on the right side of males and the left side of females had the minimum length. Whereas the third group on the right side of males and the first group on the right side of females had the minimum width and finally the first group on the right side in males and the second group on the right side in females had the minimum height.

\section{Conclusion}

To conclude, a high incidence of frontal sinus cell types and supraorbital cells was observed, suggesting that the superio-posterior partition of frontal sinus tended to demonstrate more pneumatization than other partitions. Besides, the relatively large numbers of individuals in this study mathematically proved obvious statistical differences in different age, side, and gender groups in the frontal sinus, which might be of considerable value to determine the gender, age, racial origin, and ethnic group for alive or even dead individuals.

\section{Acknowledgments}

The author is grateful to all doctors and health workers at the Radiology Section of both Baghdad Medical City and Salah Al-Deen Teaching Hospitals for their magnificent assistance and unlimited support to carry out this research successfully.

\section{Conflict of Interest}

The author declared no conflicts of interest were associated with this research because it is a scientific academic work supervised by the Iraqi Ministry of Higher Education and Scientific Research.

\section{References}

1. Kountakis SE, Senior BA, Draf W. The frontal sinus. Berlin: Springer-Verlag; 2008;159-94

2. Amin SM. External endoscopic multiportal frontal sinus obliteration for laterally 
pneumatized frontal sinus: a feasibility study. Egypt J Otolaryngol. 2018;34:105-10. [DOI:10.4103/ejo.ejo 89 17]

3. Michael JM, Charles AR, Eric LW, et al. Variability of paranasal sinus pneumatization in the absence of sinus disease. Ochsner J. 2020; 20(2):170-5. [DOI: 10.31486/toj.19.0053]

4. Dassi CS, Demarco FR, Mangussi-Gomes J, Weber R, Balsalobre L, Stamm AC. The frontal sinus and frontal recess: anatomical, radiological and surgical concepts. Int Arch Otorhinolaryngol. 2020;24(3):e364-e375. [DOI: 10.1055/s-0040-1713923]

5. Mohammad SA, Abdalla MA, Mahdi AJJ. Orbitometry of orbital opening and orbital cavity in neonate compared adult. Tikrit Med J. 2011;17:210-216.

6. Fatu C, Puisoru M, Rotaru M, Truta AM. Morphometric evaluation of the frontal sinus in relation to age. Ann Anat. 2006;188: 275-80. [DOI: 10.1016/j.aanat.2005.11.012]

7. Sahu N, Casiano R R. Nasal branch of the anterior ethmoid artery: a consistent landmark for a midline approach to the frontal sinus. Int Forum Allergy Rhinol. 2019; 9(5): 562-6. [DOI:10.1002/alr.22278]

8. Shakeri K, Abesi F, Haghanifar S, Khafri. Evaluation of the morphometric variation of frontal sinus in cone-beam computed tomography (CBCT) of paranasal sinus. Caspian J Dent Res .2020; 9: 35-41.

9. Abdalla MA, Mahdi AJJ. Maxillary sinus measurements in different age groups of human cadavers. Tikrit J Dent Sci. 2013; 1: 107-12.

10. Shahab S, Sarikhani S, Manouchehri ME , Yazdanpanah P. Assessment of frequency and anatomical characteristics of Haller cells in cone-beam computed tomography scans of patients referring to a private oral and maxillofacial radiology clinic during 20152017. J Islam Dent Assoc Iran 2018; 30: 100-5. [DOI:10.30699/JIsdreir.30.3.100]

11. Balegh AH, Moustafa T. Anatomical variations of paranasal sinuses on multidetector computed tomography. On J Otolaryngol Rhinol. 2020; 3(2): 556. [DOI:10.33552/O]OR.2020.03.000556]

12. Abdalla MA. Pneumatization patterns of human sphenoid sinus associated with the internal carotid artery and optic nerve by CT scan. Ro J Neurol. [DOI:10.37897/R]N.2020.4.5]

13. Whaites E. Essentials of dental radiography and radiology. 4th ed. Edinburgh: Churchill Livingstone; 2007. p.79-334.
14. Souza LA Jr, Marana AN, Weber SAT. Automatic frontal sinus recognition in computed tomography images for person identification. Forensic Sci Int J. 2018; 286: 252-64

[DOI:10.1016/j.forsciint.2018.03.029]

15. Han D, Zhang L, Ge W, Tao J, Xian J, Zhou B. Multiplanar computed tomographic analysis of the frontal recess region in Chinese subjects without frontal sinus disease symptoms. ORL. 2008; $\quad 70 \quad$ (2): $\quad 104-12$. [DOI: $10.1159 / 000114533]$

16. Eweiss AZ, Khalil HS. The prevalence of frontal cells and their relation to frontal sinusitis: a radiological study of the frontal recess area. $\mathrm{J}$ Otolaryngol. 2013; 68: 75-82. [DOI: 10.1155/2013/687582]

17. Tatlisumak E, Ovali GY, Aslan A, Asirdizer M , Zeyfeoglu Y , Tarhan S. Identification of unknown bodies by using CT images of frontal sinus. Forensic Sci Int J. 2007; 166(1): 42-8. [DOI: 10.1016/j.forsciint.2006.03.023]

18. Riepert T, Ulmcke D, Schweden F, Nafe B. Identification of unknown dead bodies by X-ray image comparison of the skull using the X-ray simulation program Foxsis. Forensic Sci Int J. 2001; 117: 89-98. [DOI:10.1016/S03790738(00)00452-7]

19. Akhlaghi M, Bakhtavar K, Moarefdoost J, Kamali A, Rafeifar S. Frontal sinus parameters in computed tomography and sex determination. Leg Med (Tokyo) 2016; 19: 22-7. [DOI:10.1016/j.legalmed.2016.01.008]

20. Ruiz CR , Wafae N. Anatomo-radiological and morphometrical study of the frontal sinus in humans. Braz. J. Morphol. Sci. 2004; 21(1): 536.

21. Soares CB, Caio.Belem R, Almeida MS, et al.. Human identification study by means of frontal sinus imaginological aspects. Forensic Sci Int J. 2016; 262: 183-9. [DOI: 10.1016/j.forsciint.2016.03.030]

22. Ribeiro FA. Standardized measurements of radiographic films of the frontal sinuses: an aid to identifying unknown persons. Ear Nose Throat J. 2000; 79: 26-33. [DOI:10.1177/014556130007900108]

23. Choby G, Thamboo A, Won TB, Kim J, Shih LC , Hwang PH. Computed tomography analysis of frontal cell prevalence according to the International Frontal Sinus Anatomy classification. Int Forum Allergy Rhinol. 2018; 8: 825 -30. [DOI:10.1002/alr.22105]

24. Wormald PJ, Hoseman W, Callejas C, et al. The international frontal sinus anatomy 
classification (IFAC) and classification of the extent of endoscopic frontal sinus surgery
(EFSS). Int Forum Allergy Rhinol. 2016; 6: 677-96. [DOI:10.1002/alr.21738].

\section{How to Cite This Article:}

Abdalla M A. Age Differences of Human Frontal Sinus Measurements using CT Scan. J Adv Med Biomed Res. $2021 ; 29$ (136) :293-301

\section{Download citation:}

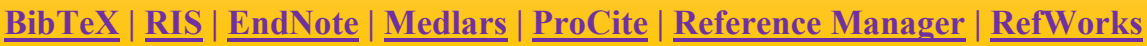

\section{Send citation to:}

Mendeley 2 Zotero RefWorks RefWorks 